\title{
Functional Capacity of Elder Elderly: Comparative Study in Three Regions of Rio Grande do Sul
}

\author{
Marinês Aires ${ }^{1}$ \\ Lisiane Manganelli Girardi Paskulin² \\ Eliane Pinheiro de Morais ${ }^{3}$
}

\begin{abstract}
Study conducted with secondary data from cross-sectional population-based studies developed in three regions of the state of Rio Grande do Sul (RS), which aimed to compare the level of dependency for activities of daily living (ADL) of 155 older persons aged 80 years and over. Demographic data and the ADL scale from the 3 studies were used and a multinomial multivariate logistic regression analysis was carried out. The older persons from the urban region of Porto Alegre/RS and from the Northern region of this state presented significantly higher severe dependency than people from the countryside. The results illustrate the heterogeneity of the aging process. Health policies and actions should be planned for the elder elderly in this state.
\end{abstract}

Descriptors: Aged, 80 and over; Activities of Daily Living; Cross-Sectional Studies.

Escola de Enfermagem, Universidade Federal do Rio Grande do Sul, Brazil:

${ }^{1}$ RN, Master's Student, Scholarship holder Capes, e-mail: marynesayres@yahoo.com.br.

2 RN, Ph.D. in Sciences, Adjunct Professor, e-mail: paskulin@orion.ufrgs.br.

${ }^{3}$ RN, Ph.D. in Nursing, Adjunct Professor, e-mail: epmorais@hotmail.com.

Corresponding Author:

Lisiane Paskulin

Escola de Enfermagem. Universidade Federal do Rio Grande do Sul

Rua São Manoel, 963

Bairro Rio Branco

CEP: 90620-110 Porto Alegre, RS, Brazil

E-mail: paskulin@orion.ufrgs.br 


\title{
Capacidade funcional de idosos mais velhos: estudo comparativo em três regiões do Rio Grande do Sul
}

Estudo realizado com dados secundários de pesquisas populacionais transversais, desenvolvidas em três regiões do Rio Grande do Sul, que teve por objetivo comparar o grau de dependência para as atividades de vida diária (AVD) de 155 idosos com 80 anos ou mais. Foram utilizadas questões demográficas e a escala de AVD dos três estudos e realizada análise multivariável de regressão logística multinomial. Os idosos da região urbana de Porto Alegre, RS, e do norte do Estado apresentaram, de modo estatisticamente significativo, maior dependência grave que aqueles da região rural. Os resultados demonstram a heterogeneidade do processo de envelhecimento, levando a se recomendar o planejamento de políticas e ações de saúde a esse grupo etário no Estado.

Descritores: Idoso de 80 anos ou mais; Atividades Cotidianas; Estudos Transversais.

\section{Capacidad funcional de ancianos com edad avanzada: estudio comparativo en tres regiones de Rio Grande del Sur}

\begin{abstract}
Se trata de un estudio realizado con datos secundarios de investigaciones poblacionales transversales, desarrolladas en tres regiones de Rio Grande del Sur, que tuvo por objetivo comparar el grado de dependencia para las actividades de la vida diaria (AVD) de 155 ancianos con 80 años o más. Fueron utilizadas preguntas demográficas y la escala de AVD de los tres estudios y realizado un análisis multivariado de regresión logística multinomial. Los ancianos de la región urbana de la ciudad de Porto Alegre y del norte del Estado presentaron, de modo estadísticamente significativo, una mayor dependencia grave que aquellos de la región rural. Los resultados demuestran la heterogeneidad del proceso de envejecimiento, lo que nos lleva a recomendarse la planificación de políticas y acciones de salud dirigidas a ese grupo de personas con la misma edad, en el Estado de Rio Grande del Sur, en Brasil.
\end{abstract}

Descriptores: Ancianos de 80 años y más; Actividades Cotidianas; Estudios Transversales.

\section{Introduction}

In developing countries, the demographic transition is characterized, among other factors, by a rapid and progressive increase in the number of elderly people. Statistical projections appoint that, in 2050, elderly people will represent $16 \%$ of the Brazilian population. In absolute terms, these projections rank Brazil sixth in terms of elderly population in the world, with more than 32 million people. In Brazil, between 1997 and 2007, the increase in the population in general amounted to $21.6 \%$, against $47.8 \%$ for the group aged 60 years or older(1). Moreover, the rise in the proportion of people aged 80 years or older has resulted in an altered composition of the elderly population ${ }^{(2)}$. Hence, it is important to observe the characteristics of this age group.
Elderly health can be assessed through functional capacity, which is a result of the interaction between physical and mental health, independence in daily living, social integration, family support, economic independence and service use(3). Usually, functional capacity is assessed by the ability to perform activities of daily living (ADL).

Research has identified, among factors associated with decreased functional capacity, variables related to socioeconomic and demographic aspects ${ }^{(4-6)}$. One study involved elderly in urban São Paulo and evidenced the association between advanced age and greater dependence for ADLs among elderly older than 80 , up to 36 times more than among other elderly(4). 
Earlier research published in this journal highlights the importance of elaborating and putting in practice strategies to promote the health and quality of life of this population ${ }^{(7-8)}$. The lack of studies on the functional capacity of elder elderly in Brazil and other developing countries aroused the researchers' interest to compare the findings of two doctoral dissertations ${ }^{(9-10)}$ and one undergraduate Nursing monograph(11) on the theme, carried out in three regions of Rio Grande do Sul (RS), Brazil. The researchers believe this study will contribute to knowledge production on the functional capacity of elderly people aged 80 years or older and that, by comparing rural and urban elderly, will support the planning of public policies and health service interventions in this age group's different life contexts, besides furthering research on rural and urban aging.

Functional capacity assessment is a professional challenge that needs to be faced, in view of the heterogeneity of the aging process and the influences of different factors the families of elderly can be subject to. This panorama creates new demands for the entire health area, especially nursing. The challenge these professionals are confronted with is to go beyond the clinical/curative approach towards multiprofessional and interdisciplinary actions, with a view to preserving the elderly people's autonomy and independence, promoting active aging with quality of life and supporting these people's family and caregivers.

This research aimed to compare the level of dependency for ADLs among elderly aged 80 years or older in three regions of Rio Grande do Sul.

\section{Methods}

A research was carried out, using secondary data from cross-sectional epidemiological studies carried out in three regions of Rio Grande do Sul, between 2006 and $2007^{(9-11)}$. All participants in the three studies who were 80 years of age or older and were able to answer the research instruments without help were selected from the respective databases, totaling a sample of 155 elderly.

The regions under study were the rural zone of a city in the South of the state ${ }^{(9)}$, an urban district of Porto Alegre $^{(10)}$ and the urban zone of a Northern city ${ }^{(11)}$.

The first place of study was the rural zone of Encruzilhada do Sul, the region with the second largest proportion of elderly people in the Southern half of the state. The city had 23,902 inhabitants, 14,841 living in the urban and 9,061 in the rural zone. The total number of elderly in the city amounted to $3,174,1,454$ of whom lived in the rural context ${ }^{(1)}$. In this group, 155 were 80 years of age or older, and 96 were able to answer the research instruments without help ${ }^{(9)}$.

The second place of study was an urban area of Porto Alegre (Northeastern Health District), with the second largest proportion of elderly people in the city. The city's total population in the year 2000 corresponded to $1,360,590$ people, 160,240 of whom were elderly $(11.8 \%)$. The population in the area covered by the study amounted to 129,905 inhabitants, 20,302 in the group aged 60 years or older ${ }^{(1)}$. The sample consisted of 292 elderly people, 43 of whom were 80 years of age or older and able to answer the interview ${ }^{(10)}$.

The third place of study was Frederico Westphalen, a city in the North of the state. The study was carried out in the area covered by the Family Health Strategy (FHS) in the urban area of the city. The city has approximately 28 thousand inhabitants; according to census data, the elderly population included 2,536 (9.40\%) people ${ }^{(1)}$. The FHS, as the scenario for this research, delivered care to 3,868 people, divided in five micro-areas. The sample consisted of 176 elderly people, 16 of whom were 80 years of age or older and able to answer the interview $^{(11)}$.

In the three original studies, the elderly were either selected through probabilistic sampling(10-11) or represented the total population in the study region ${ }^{(9)}$. Data were collected through home inquiries and instruments, which permitted addressing socioeconomic and demographic variables as well as functional capacity.

The database variables used were gender, age group, marital status and education level. The outcome variable was the elderly people's level of dependence of ADLs. This level was assessed by applying the scale of ADLs, composed of basic and instrumental activities of daily living (BADL and IADL, respectively). For each individual, the number of "needs help" and "does not need help" answers were quantified, using the following categories: independent, mild dependency, moderate dependency and severe dependency ${ }^{(12)}$.

Data were administered in SPSS 13.0. In this research, bivariate analysis was performed using Pearson's chi-square test. Variables with $p<0.25$ in bivariate analysis were included in multinomial and multivariate logistic regression analysis, in which the reference category for the outcome was independence. As for location, the rural region was used as the baseline. Significance level was set at $5 \%$, with $p$-values $<0.05$ being considered statistically significant. 
The original projects got approval from the Research Ethics Committee at São Paulo Federal University (No 0423/04)(9), Research Ethics Committee at Ribeirão Preto College of Nursing (No 0629/2005)(10) and Ethics Committee at Universidade Regional Integrada do Alto Uruguai e das Missões (No 0003-06H) ${ }^{(11)}$. All participants signed the free and informed consent term. The researchers of the original studies are the authors of the present research.

\section{Results}

The results of the sociodemographic characteristics of elderly aged 80 years or older (Table 1 ) indicate the predominance of women in the rural region (60.4\%) and in the Porto Alegre district (79.1\%). In the North of the State, $56.3 \%$ of the elderly were men. As for age group, in the three regions, the age range from 80 to 84 years prevailed. In the rural region, $70.8 \%$ of the elderly did not have a partner, against $76.7 \%$ in the urban region of Porto Alegre. In the Northern region of the state, most elderly (56.3\%) lived with a partner. With regard to education, in the rural region, a larger proportion of elderly was illiterate or had not finished primary education (94.3\%). The same was true for the urban region of RS (87.5\%). In urban Porto Alegre, on the other hand, equal proportions (41.9\%) were found between elderly who were illiterate or had not finished primary education and those with primary/secondary education. In the same region, $16.3 \%$ of the elderly had finished a secondary or higher education course.

Table 1 - Distribution of sociodemographic variables of elderly people aged 80 years or older, according to place of origin in three regions of RS. Porto Alegre, 2008

\begin{tabular}{|c|c|c|c|c|}
\hline \multirow{4}{*}{ Variables } & \multicolumn{3}{|c|}{ Locations } & \multirow{4}{*}{$p^{*}$} \\
\hline & Rural region & Urban region $\mathrm{POA}$ & Urban region & \\
\hline & $(n=96)$ & $(n=43)$ & Northern RS ( $n=16)$ & \\
\hline & n (\%) & n (\%) & $n(\%)$ & \\
\hline \multicolumn{5}{|l|}{ Gender } \\
\hline Male & $38(39.6)$ & $9(20.9)$ & $9(56.3)$ & 0.022 \\
\hline Female & $58(60.4)$ & $34(79.1)$ & $7(43.8)$ & \\
\hline \multicolumn{5}{|l|}{ Age range } \\
\hline $80-84$ & $60(62.5)$ & $24(55.8)$ & $10(62.5)$ & 0.776 \\
\hline $85-89$ & $26(27.1)$ & $16(37.2)$ & $5(31.3)$ & \\
\hline$\geq 90$ & $10(10.4)$ & $3(7)$ & $1(6.3)$ & \\
\hline \multicolumn{5}{|l|}{ Partner } \\
\hline With & $28(29.2)$ & $10(23.3)$ & $9(56.3)$ & 0.046 \\
\hline Without & $68(70.8)$ & $33(76.7)$ & $7(43.8)$ & \\
\hline \multicolumn{5}{|l|}{ Education } \\
\hline Illiterate/unfinished primary & $83(94.3)$ & $18(41.9)$ & $14(87.5)$ & $<0.001$ \\
\hline Primary/secondary & $5(5.7)$ & $18(41.9)$ & $2(12.5)$ & \\
\hline Secondary/higher education & $0(0)$ & $7(16.3)$ & $0(0)$ & \\
\hline
\end{tabular}

* Pearson's chi-square test

The results of the association between the study variables and the classification of the elder elderly people's total ADL score, as shown in Table 2, indicate a trend for men to be more independent than women $(p=0.057)$. The group with a smaller proportion of women $(54.1 \%)$ is that of independent elderly. As for age range, only $28.6 \%$ of severely dependent elderly people were between 80 and 84 years old, while this age range prevailed in all other dependency levels (>60\%). This association was not statistically significant, however $(p=0.183)$.
As for education level, in all dependency levels, most elderly people were either illiterate or had not finished primary education (less than four years of study), without any statistical association between this variable and the dependent variable either $(p=0.891)$. With regard to the place of residence, a statistical association was found between this variable and the level of dependency $(p=0.003): 57.1 \%$ of elderly people with severe dependency lived in the urban region of Porto Alegre, while $73.3 \%$ of elderly with moderate dependency, $53.8 \%$ with mild dependency and $71.8 \%$ of independent elderly lived in the rural region. 
Table 2 - Association between variables of interest and dependency level for ADLs among elderly aged 80 years or older, in three regions of RS. Porto Alegre, 2008

\begin{tabular}{|c|c|c|c|c|c|}
\hline \multirow{3}{*}{ Variables } & \multicolumn{4}{|c|}{ Dependency level } & \multirow{3}{*}{$p^{*}$} \\
\hline & $\begin{array}{l}\text { Independent } \\
\qquad(n=85)\end{array}$ & $\begin{array}{c}\text { Mild } \\
\text { dependency } \\
(n=39)\end{array}$ & $\begin{array}{c}\text { Moderate } \\
\text { dependency } \\
(n=15)\end{array}$ & $\begin{array}{c}\text { Severe } \\
\text { dependency } \\
(n=14)\end{array}$ & \\
\hline & n (\%) & n (\%) & n (\%) & n (\%) & \\
\hline \multicolumn{6}{|l|}{ Gender - n (\%) } \\
\hline Male & $39(45.9)$ & $11(28.2)$ & $3(20)$ & $3(21.4)$ & 0.057 \\
\hline Female & $46(54.1)$ & $28(71.8)$ & $12(80)$ & $11(78.6)$ & \\
\hline \multicolumn{6}{|l|}{ Age range $-\mathrm{n}(\%)$} \\
\hline $80-84$ & $56(65.9)$ & $24(61.5)$ & $9(60)$ & $4(28.6)$ & 0.183 \\
\hline $85-89$ & $24(28.2)$ & $10(25.6)$ & $4(26.7)$ & $8(57.1)$ & \\
\hline$\geq 90$ & $5(5.9)$ & $5(12.8)$ & $2(13.3)$ & $2(14.3)$ & \\
\hline \multicolumn{6}{|l|}{ Marital status - n (\%) } \\
\hline With & $34(40)$ & $9(23.1)$ & $3(20)$ & $1(7.1)$ & 0.030 \\
\hline Without & $51(60)$ & $30(76.9)$ & $12(80)$ & $13(92.9)$ & \\
\hline \multicolumn{6}{|l|}{ Education level - n (\%) } \\
\hline Illiterate/unfinished primary & $65(80.2)$ & $25(71.4)$ & $11(73.3)$ & $12(85.7)$ & 0.891 \\
\hline Primary/secondary & $12(14.8)$ & $8(22.9)$ & $3(20)$ & $2(14.3)$ & \\
\hline Secondary/higher education & $4(4.9)$ & $2(5.7)$ & $1(6.7)$ & $0(0)$ & \\
\hline \multicolumn{6}{|l|}{ Location - n(\%) } \\
\hline Rural region & $61(71.8)$ & $21(53.8)$ & $11(73.3)$ & $3(21.4)$ & 0.003 \\
\hline Urban region $\mathrm{POA}$ & $14(16.5)$ & $16(41)$ & $3(20)$ & $8(57.1)$ & \\
\hline Urban region Northern RS & $10(11.8)$ & $2(5.1)$ & $1(6.7)$ & $3(21.4)$ & \\
\hline
\end{tabular}

* Pearson's chi-square test

The results of the logistic regression analysis (Table 3) showed that the elderly people's dependency level for ADLs was associated with age range and place of residence. Gender and marital status were also included in the model, but without any significant association. Elderly in the range from 85 to 90 years old and aged 90 years or older displayed higher levels of severe dependency ( $O R=4.88 ; C I 95 \%=1.11-21.4$; $\mathrm{p}=0.036$ and $\mathrm{OR}=9.72 ; \mathrm{CI} 95 \%=1.11-84.8 ; \mathrm{p}=0.040$, respectively) when compared with elderly between 80 and 84 years of age.
Elderly in urban Porto Alegre and the North of the state showed higher levels of severe dependency than elderly in the rural region $(\mathrm{OR}=10.1 ; \mathrm{CI} 95 \%=2.13$ 47.5; $\mathrm{p}=0.004$ and $\mathrm{OR}=16.7 ; \mathrm{CI} 95 \%=2.20-126.8$; $\mathrm{p}=0.006$, respectively). Moreover, an association was found between mild dependency and place of residence in urban Porto Alegre $(\mathrm{OR}=3.44$; $\mathrm{CI} 95 \%=1.39-8.53$; $\mathrm{p}=0.008$ ), that is, elderly living in the urban region displayed greater mild dependency than those in the rural region. No associations were found between age range and location on the one hand and moderate dependency on the other.

Table 3 - Analysis of multinomial logistic regression in three distinct regions, adjusted by variables associated with ADL of elderly aged 80 years or older. Porto Alegre, 2008

\begin{tabular}{|c|c|c|c|c|c|c|}
\hline \multirow{2}{*}{ Variables* } & \multicolumn{2}{|c|}{ Severe dependency } & \multicolumn{2}{|c|}{ Moderate dependency } & \multicolumn{2}{|c|}{ Mild dependency } \\
\hline & OR (Cl 95\%) & $p$ & OR (Cl 95\%) & $p$ & OR (Cl 95\%) & $\mathbf{p}$ \\
\hline \multicolumn{7}{|l|}{ 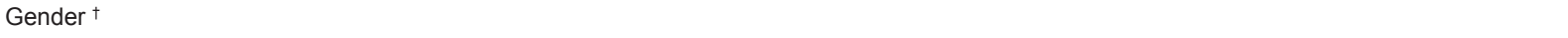 } \\
\hline Female & $3.13(0.56-17.4)$ & 0.194 & $3.09(0.69-13.8)$ & 0.139 & $1.59(0.62-4.08)$ & 0.334 \\
\hline Male & 1.00 & & 1.00 & & 1.00 & \\
\hline \multicolumn{7}{|l|}{ Partner } \\
\hline With & $0.11(0.01-1.09)$ & 0.059 & $0.60(0.13-2.68)$ & 0.501 & $0.56(0.21-1.48)$ & 0.240 \\
\hline Without & 1.00 & & 1.00 & & 1.00 & \\
\hline \multicolumn{7}{|l|}{ Age range $^{\dagger}$} \\
\hline $80-84$ & 1.00 & & 1.00 & & 1.00 & \\
\hline $85-89$ & $4.88(1.11-21.4)$ & 0.036 & $1.29(0.34-4.89)$ & 0.711 & $1.00(0.39-2.58)$ & 0.999 \\
\hline$\geq 90$ & $9.72(1.11-84.8)$ & 0.040 & $3.35(0.52-21.6)$ & 0.204 & $3.08(0.75-12.7)$ & 0.120 \\
\hline \multicolumn{7}{|l|}{ Location } \\
\hline Rural region & 1.00 & & 1.00 & & 1.00 & \\
\hline Urban region $\mathrm{POA}$ & $10.1(2.13-47.5)$ & 0.004 & $1.13(0.27-4.78)$ & 0.872 & $3.44(1.39-8.53)$ & 0.008 \\
\hline Urban region Northern RS & $16.7(2.20-126.8)$ & 0.006 & $0.81(0.08-7.74)$ & 0.852 & $0.79(0.15-4.14)$ & 0.785 \\
\hline
\end{tabular}

*All variables are controlled for others of the same level and higher levels. The reference category of the outcome is independence. The categories of the predictive variables that received Odds Ratios of 1.00 are reference categories.

${ }^{\dagger}$ Variables with significance level between 5 and $25 \%$ were maintained in the model to control confusion. 


\section{Discussion}

The prevalence of female elderly in two regions is similar to other studies involving elderly aged 80 years or older ${ }^{(7-8,13-14)}$. It is known that urban areas present a largest proportion of women in comparison with rural zones $^{(2)}$. The smaller proportion of women in the North of the state can be associated with the size of the study sample when compared with the other two studies, or correspond to the reality of a medium-sized city ${ }^{(11)}$. The feminization of old age is ongoing: the proportion of women increases with the age of the study segment. Women's higher life expectancy can be explained by different factors, including lesser consumption of alcoholic drinks and tobacco, decreased maternal mortality and differences in exposure to risk factors for mortality by external causes, such as traffic accidents, homicides and others ${ }^{(2)}$.

As for age, the age range from 80 to 84 years predominated, like in other studies on elderly aged 80 years or older $(7,13)$. The marital status without a partner prevailed for elderly from the rural region and from urban Porto Alegre, as identified in another research in the Porto Alegre region(15). In the North of the state, on the other hand, elderly with a partner prevailed, perhaps due to the greater proportion of male elderly. Similar data were found in a Portuguese study carried out in a rural zone of Montemor-o-Velho and an urban zone of Coimbra, in which the authors observed the prevalence of married elderly in the urban region and widowed and single elderly in the rural region ${ }^{(14)}$.

As for education level, high levels of illiteracy are expected to be associated, among other factors, with access difficulties to schools, mainly outside large urban centers, in view of the larger proportion of illiterate people or with unfinished primary education in the rural region, as well as in the urban region of RS. In the urban region of Porto Alegre, on the other hand, equal proportions of illiterate elderly or with unfinished primary education and those with primary/secondary education were found. The study carried out in Portugal evidenced similar results when comparing rural and urban elderly. The authors identified, with a statistically significant difference, that most elderly in the rural area were illiterate, while the group in the urban region had finished primary education ${ }^{(14)}$.

According to studies carried out in São Paulo city, the commitment of elderly people's functional capacity for ADLs was associated with age ${ }^{(4-6)}$. In the present study, the researchers also found an association between severe dependency and more advanced age.
One surprising finding was the absence of a statistically significant association between gender and functional capacity, differently from other studies in which functional incapacity was associated with the female gender(4-6,16-17). No association was found for the marital status variable either when included in the logistic regression model. A similar result was found in a research carried out in the metropolitan region of Belo Horizonte, in which marital status was not associated with the elderly people's functional incapacity ${ }^{(17)}$.

Elderly from the urban region of Porto Alegre and the North of the state showed higher statistically significant levels of severe dependency than those in the rural region. These results were similar to the study in a sample of elderly women, in which living in the rural region was also associated with decreased prevalence of functional incapacity(18). It can be speculated on that the daily reality of people living and working on the fields makes them more apt to reach advanced age with higher levels of functionality.

\section{Conclusion}

This research aimed to sketch a panorama of elderly people aged 80 years or older as to their dependency level for ADLs in three regions of Rio Grande do Sul. Among the results, the following stand out: predominance of women in two of the three study regions; predominance of the age range between 80 and 84 years in the three regions; greater proportion of illiterate people or with unfinished primary education among elderly in the rural region and in the Northern urban region and greater independence for ADLs among elderly in the rural region.

The accelerated growth in the number of elder elderly in Brazil demands that a new direction be given to public policies, with a view to putting in practice strategies that are adequate to the population's needs. The obtained results strengthen the need for elderly health care to be based on the principles of the Unique Health System, with a view to care integrality, and guided by the maintenance of autonomy and functional capacity. In this sense, nurses play a paramount role in different urban and rural scenarios, working in basic and specialized care as agents who transform care practices, calling attention to the complexity of the aging process.

Further studies could explore factors related to the maintenance of functional capacity among elderly in rural areas, based on the observation of higher independence levels in this context. 


\section{References}

1. Instituto Brasileiro de Geografia e Estatística. Indicadores sociais [documento na internet]. Brasília (DF); 2002 [Acesso em: 17 setembro 2007]. Disponível em: http://ftp.ibge.gov. br/Indicadores_Sociais/Sintese_de_Indicadores_Sociais_2002/ aspectos_demograficos.zip.

2. Camarano AA. Como vive o idoso brasileiro? In: Camarano, AA, organizador. Os novos idosos brasileiros: muito além dos 60 ? Rio de Janeiro: IPEA; 2004. p. 25-77.

3. Ramos LR. Fatores Determinantes do Envelhecimento Saudável em Idosos Residentes em Centro Urbano: Projeto Epidoso, São Paulo. Cad Saúde Pública 2003 maio; 19(3):793-8.

4. Rosa TEC, Benício MHD, Latorre MRDO, Ramos LR. Fatores determinantes da capacidade funcional entre idosos. Rev Saúde Pública 2003 fevereiro; 37(1):40-8.

5. Duarte YAO. Desempenho funcional e demanda assistencial. In: Lebrâo ML, Duarte YAO. SABE: Saúde Bem-Estar e Envelhecimento. O Projeto Sabe no município de São Paulo: Uma abordagem Inicial. Brasília: Organização Pan-Americana da Saúde; 2003. p.169-81.

6. Fiedler MM, Peres KG. Capacidade funcional e fatores associados em idosos do Sul do Brasil: um estudo de base populacional. Cad Saúde Pública, 2008 fevereiro; (24): 409-15. 7. Orb A. Aspectos de salud en adultos mayores de 80 anos de edad que viven independientemente en la comunidad: una perspectiva australiana. Rev Latino-am Enfermagem 2004; 12(4):589-96.

8. Inouye $\mathrm{K}$, Pedrazzani ES. Instruction, social economic status and evaluation of some dimensions of octogenarians' quality of life. Rev Latino-am Enfermagem 2007 setembro; 15(número especial): 742-747.

9. Morais EP. Envelhecimento no meio rural: condições de vida saúde e apoio aos idosos mais velhos no município de Encruzilhada do Sul/RS. [tese]. São Paulo: Escola de Enfermagem de Ribeirão Preto/USPRP; 2007.
10. Paskulin LMG. Fatores associados à qualidade de vida dos idosos de um $m$ distrito sanitário na região de Porto Alegre/ RS. [tese]. São Paulo: Escola Paulista de Medicina/ Programa de Pós-Graduação em Enfermagem da Universidade Federal de São Paulo; 2006.

11. Aires M. As necessidades de cuidado no domicílio das pessoas idosas no contexto do Programa de Saúde da Família [trabalho de conclusão de curso]. Frederico Westphalen: Curso de Bacharelado em Enfermagem, Universidade Regional Integrada do Alto Uruguai e das Missões; 2006.

12. Ramos LR, Rosa TEC, Oliveira ZM, Medina MCG, Santos FRG. Perfil do idoso em área metropolitana na região sudeste do Brasil: resultados de inquérito domiciliar. Rev Saúde Pública 1993 abril; 27(2):87-94.

13. Inouye K, Pedrazzani ES, Pavarini SCL. Octogenários e cuidadores: perfil sócio-demográfico e correlação da variável qualidade de vida. Texto contexto - enferm. 2008 abril; (17)2:350-7.

14. Nina E, Paiva C. Idosos rurais e urbanos: estudo comparativo. Geriatria 2001 novembro; 14(138):9-32.

15. Souza LM, Morais EP, Barth QCM. Socioeconomic and demographic characteristics and health condition of elderly people from a family health program in Porto Alegre, Brazil. Rev Latino-am Enfermagem 2006; 14(6):901-6.

16. Von Strauss E, Fratiglioni L, Viitanen M, Forsell $Y$, Winblad B. Morbidity and comorbidity in relation to functional status: $A$ community -Based study of the old (90+ years). J Am Geriatr Soc New York 2000 November; 48(11):1462-9.

17. Giacomin KC, Peixoto SV, Uchoa E, Lima-Costa MF. Estudo de base populacional dos fatores associados à incapacidade funcional entre idosos na Região Metropolitana de Belo Horizonte, Minas Gerais, Brasil. Cad Saúde Pública 2008 junho; 24(6):1260-70. 18. Parahyba MI, Veras R, Melzer D. Incapacidade Funcional entre as mulheres idosas no Brasil. Rev de Saúde Pública 2005 junho; 39(3):383-91. 